\title{
Monitoring the Influence of Anthropogenic Pollution on the Quality of Irrigation Water for Market Gardening in Yamoussoukro, Côte d'Ivoire
}

Tchimonbié Messikely Anoman, Don-Rodrigue Rosin Bi Voko', Dabé Doga², Aka Niangoran Marie Stephanie Kouadio', Konan Samuel Ahoudjo ${ }^{3}$, Adolphe Zeze

10.18805/IJARe.A-586

\begin{abstract}
Background: The microbiological quality of three vegetable crops (cabbages, carrots, lettuces) and their irrigation water from the lake system of the city of Yamoussoukro were studied. The pollution indicator used is Escherichia coli (E. coli), of the thermotolerant coliform family.

Methods: During the period 2017-2019, in four dry and four wet seasons, a total of 744 water samples and 13392 vegetable samples were collected in five (5) lakes belonging to the lake system. The lakes were selected because of their position in the system. The $E$. coli loads were evaluated after isolation on a specific COMPASS ECC Agar and confirmed with polymerase chain reaction (PCR) and the physicochemical parameters of the lakes, evaluated according to their respective ISO standards.

Result: In irrigation waters, bacterial loads and physico-chemical parameters generally have evolved from the upstream lakes to those downstream of the lake system (from lake A to lake E). Values were higher during the rainy seasons. E. coli loads on vegetables were strongly correlated with those of irrigation water, especially in dry seasons. Spearman's correlations revealed significant correlations between turbidity, DOC and bacterial loads. The risk of bacterial transmission between lake waters and surrounding vegetables is proven.
\end{abstract}

Key words: Lakes waters, Sanitary quality, Vegetable crops.

\section{INTRODUCTION}

Yamoussoukro, in Côte d'Ivoire is characterized by a principal lacustrine system ten (10) lakes (N'Guessan et al., 2011). Market gardening is the most important economic activity developed around the lakes, whose waters are the main sources of irrigation (Tano et al., 2011).

The diversity of activities practiced in and around the lakes (agriculture, fishing, commercial activities, animal husbandry, laundry, washing, ablutions and dishes) constitute sources of contamination of lakes waters (Anoman et al., 2019; Edosomwan and Onwumah, 2008). Unfortunately, the use of polluted water for irrigation is common in Africa and represents a risk for the populations (Amoah et al., 2007). Indeed, the timing of watering, the quality and direct contact of the water with the edible part of the plant are all risk factors (WHO, 2012). For example, vegetables produced around the Yamoussoukro lakes may pose food threats because they are eaten raw and generally without good decontamination practices (Sylla et al., 2019).

Several countries and international organizations such as the World Health Organization (WHO) and the Food and Agriculture Organization of the United Nations (FAO) have developed codes of practice, guidelines and regulations (FAO, 2008; WHO, 2012; USDA, 2014) with measures that can be used to prevent and control microbial hazards throughout the fresh vegetable supply chain. However, in Côte d'Ivoire, it is difficult for such measures to be implemented.

Thermotolerant coliforms, including Escherichia coli, are a bacterial group used as an indicator of faecal
UMRI Sciences Agronomiques et Génie Rural, Institut National Polytechnique Felix Houphouët-Boigny (INP-HB), BP 1313 Yamoussoukro, Côte d'Ivoire.

${ }^{1}$ Departement de Biochimie-Microbiologie, Université Jean Lorougnon Guédé, 12 BP V 25 Daloa, Côte d'ivoire.

${ }^{2}$ Centre National de Recherche Agronomique de Côte d'Ivoire (CNRA), Adiopodoumé, Km 17 Route de Dabou, 01 BP 1740 Abidjan 01

3UMR Marchés, Organisations, Institutions et Stratégies d'Acteurs (MOISA), Montpellier SupAgro, Campus de La Gaillarde, 34060 Montpellier Cedex 02, France.

Corresponding Author: Tchimonbié Messikely Anoman, UMRI Sciences Agronomiques et Génie Rural Institut National Polytechnique Felix Houphouët-Boigny (INP-HB), BP 1313 Yamoussoukro, Côte d'Ivoire. Email: messikely.anoman@inphb.ci How to cite this article: Anoman, T.M., Voko, D.R.R.B., Kouadio, A.N.M.S., Doga, D., Ahoudjo, K.S. and Zeze, A. (2021). Monitoring the Influence of Anthropogenic Pollution on the Quality of Irrigation Water for Market Gardening in Yamoussoukro, Côte d'Ivoire. Indian Journal of Agricultural Research. 55(6): 715-720. DOI: 10.18805/ IJARe.A-586.

Submitted: 14-07-2020 Accepted: 27-04-2021 Online: 06-09-2021

contamination according to the French standard NF IN ISO 7027(Rodier, 2009).

Their presence in the aquatic environment is evidence of recent environmental contamination by fecal matter. 
Monitoring the Influence of Anthropogenic Pollution on the Quality of Irrigation Water for Market Gardening in Yamoussoukro, ....

In addition, coliform counts are an indicator of the presence of pathogenic bacteria (WHO, 2012; Sylla et al., 2019). Thus, the objectives of this study were to monitor the dynamics of bacterial pollution in the lakes of Yamoussoukro and its impact on the contamination of market garden crops watered by the lake waters.

\section{MATERIALS AND METHODS Presentation of the study area}

Yamoussoukro, located between $6^{\circ} 40^{\prime}$ and $7^{\circ}$ North latitude and between $5^{\circ} 10^{\prime}$ and $5^{\circ} 20^{\prime}$ West longitude, is the political capital of Côte d'Ivoire (FAO, 2008). E. coli loads monitoring was conducted on five lakes in the Yamoussoukro lake system, selected because of their position in this system (Fig 1). Concerning the activities carried out in their vicinity, Lake $A$ is located in a sparsely urbanized area, Lake B in the densely populated urban center, Lakes $C$ and $D$ are located near the Regional Hospital Center (RHC) and are characterized by several domestic wastewater flows and finally, Lake $E$ is home to several livestock activities.

\section{Water sampling and isolation of Escherichia colistrains}

For each lake, $500 \mathrm{ml}$ of water was collected at 31 points according to (MDDEFP, 2013)based on the total surface of each lake. Eight (8) sampling campaigns were carried out seasonally (2 large dry seasons, 2 large rainy seasons, 2 small dry seasons and 2 small rainy seasons).

E. coli strains were isolated on a chromogenic selective agar ECC Compass Agar after incubation for $24 \mathrm{~h}$ at $44^{\circ} \mathrm{C}$ (Fricker et al., 2008). The nature of the E. coli strains was also confirmed by $\mathrm{PCR}$ using primers $E$. coli $\mathrm{R}$ ( $5^{\prime}$-ACGC GTGGTTAACAGTCTTGCG-3') and E. coli F (5'-AAAACG
GCAAGAAAAAGCAG-3') (Tsai et al., 1993). DNA was extracted from selected strains of $E$. coli using the alkaline lysis method (Birnboim and Doly, 1979).

PCR amplification was performed in a volume of $25 \mu \mathrm{l}$ containing DNA (15 ng. $\mu \mathrm{l}-1), 10 \mu \mathrm{l}$ from Master Mix, $2.5 \mu \mathrm{l}(5$ $\mu \mathrm{M})$ for the 2 primers, dNTP $(10 \mathrm{mM})$. The PCR programme consisted of 35 cycles of denaturation at $94^{\circ} \mathrm{C} / 50 \mathrm{~s}$, annealing at $53^{\circ} \mathrm{C} / 40 \mathrm{~s}$ and elongation at $72^{\circ} \mathrm{C} / 30 \mathrm{~s}$ (Schmidt et al., 2010). Ten microliters of each amplifier were placed on $1 \%$ agarose gel in TBE buffer and then in $0.5 \mu \mathrm{g} / \mathrm{ml}$ Ethidium bromide to verify the expected size.

Study of the sources of pollution by physico-chemical analyses of each lake studied

Physico-chemical analyses were carried out in the chemistry and food engineering laboratory at the Institut National Polytechnique Félix Houphouet Boigny (INP-HB) in Yamoussoukro.

The dissolved oxygen (DO) was measured using an HQ40d Portable Multi-Parameter Meter (Hach, USA) [ISO 5814, 2012 (Rodier, 2009)]. Turbidity was measured using a 430 IR/T Portable Turbimeter) [ISO 7027-1, 2016 (Rodier, 2009)]. Dissolved organic carbon (DOC), was measured by dosage with the Thermo reactor ECO 8 (Velp Scientifica, ITALY) and the spectrophotometer DR/2010 (HACH, Colorado USA) [(ISO 8245, 1999 (Rodier, 2009)]. Temperature and $\mathrm{pH}$ was measured in situ during sampling with a portable pH meter HI 991001 (Hanna Instruments Canada) [ISO 9963-1, 1994 (Rodier, 2009)]. The Ammoniacal nitrogen $\left(\mathrm{NH}_{4}^{+}\right)$; the nitrate $\left(\mathrm{NO}_{3}^{-}\right)$and the orthophosphates $\left(\mathrm{PO}_{4}{ }^{3-}\right)$ were evaluated according to the colorimetric method based on the use of the UV-visible spectrophotometer using the Nessler reagent according to the [NFT 90-015 (Rodier, 2009)] standard.

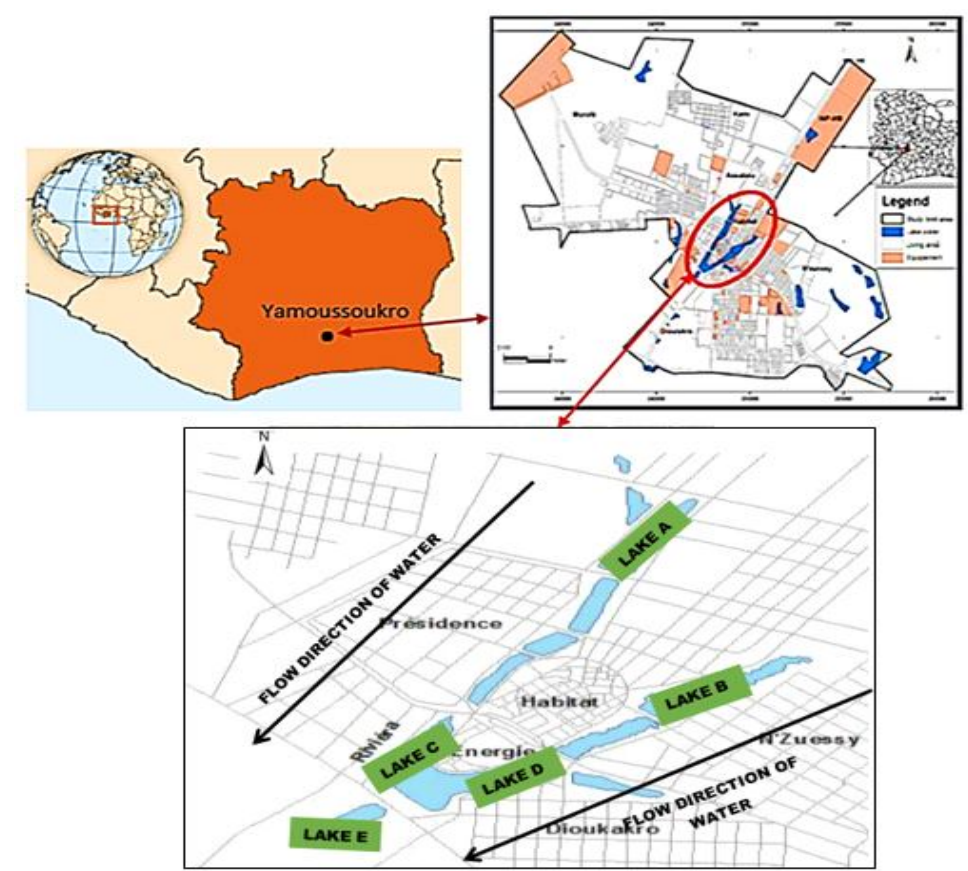

Fig 1: Map of the Yamoussoukro hydrographic network and location of the lakes defined for sampling. 


\section{Statistical analysis}

All analyses and graphical representations were performed using the statistical software $\mathrm{R}$ version 3.0.2 and XIStat 2014.Ink. The significant differences in the physico-chemical parameters of the lakes were investigated using the analysis of variance (ANOVA), followed by the least significant Newman-Keuls difference test at the probability level $p=0.05$. Multiple linear regressions and Spearman's correlation were also performed to determine the different possible relationships between parameters.

\section{RESULTS AND DISCUSSION}

\section{Characterization of anthropogenic pollution sources of} lake waters by the physico-chemical parameters

As shown in Table 1, over the years, dissolved oxygen (DO), $\mathrm{pH}$ and temperature did not show statistical differences at the $5 \%$ level. For the other parameters, there was a variation. Values were generally increased from Lake A to Lake $E$ with higher values during rainy seasons, GRS (great rain season) and SRS (short rain season). This result is similar to that of Shivakrishna et al., (2020) in India, which shows better water quality in the post-monsoon season. The post-monsoon, which corresponds to the withdrawal of rains after the monsoon, could be similar to the SRS in the Ivorian climate according to the explanations of Emon et al. (2020).

To highlight the similarities or differences between the lakes, a hierarchical cluster analysis (HCA) of the physicochemical characteristics was carried out. The dendrogram has shown that the similarities are influenced by the direction of water flow in the system. They evolve from Lake A upstream of the system to Lake $E$ downstream of the system and receptacle of all the other lakes (Fig 2). According to El-Amier et al., (2015), the downstream lakes are more rich in nutrients than those upstream due to the greater presence of suspended matter in the waters.
Impacts of irrigation water on the transmission of Escherichia coli populations on vegetables

In all five lakes studied, the average bacterial loads of Escherichia coli $703,9^{\mathrm{b}} \pm 195,18(2017-2018)$ and $685,1^{\mathrm{b}} \pm 206$, 45 (2018-2019) were been not influenced by the years. They evolved from Lake A to Lake E. In fact, the bacterial loads evolved according to the direction of the water flow of the lacustrine system (Fig 3A). These observations on the effect of the spatial position of lakes are similar to those of Akaninwor et al., (2007) on the New-Calabar River in Nigeria.

Vegetable crops with high bacterial loads were found near lakes with higher bacterial loads. In order to verify the impact of contamination of lakes (water used for watering) on that of vegetables grown around them, a linear regression was carried out between the bacterial loads in Escherichia coli of lakes on those of vegetables. It was obtained that the average loads of vegetable crops varied proportionally with the average loads of lakes waters with high positive correlation (Fig 3B). These results are similar to those of several authors (Tano et al., 2011; Kanwar and Sanda, 2000).

Impacts of climatic seasonson the evolution of $E$ coli loads in lake waters and on vegetables

It has been observed that bacterial loads change with the climatic seasons (Fig 4A). During the two years, peaks of Escherichia coli loads were obtained during the Great Rainy Seasons (GRS). The bacterial loads of the waters were greater during the rainy seasons and lower during the dry seasons while the opposite results were observed in the vegetables where the bacterial loads were greater during the dry seasons and lower during the rainy seasons (Fig 4B). The opposite result regarding the contamination of vegetables could be explained by the cultivation practices of market gardeners (Holvoet et al., 2015). In fact, they make heavy use of lakes water during dry seasons. This practice is common in Africa. In Rwanda, about $60 \%$ of farmers irrigate their vegetables during dry seasons, while the others

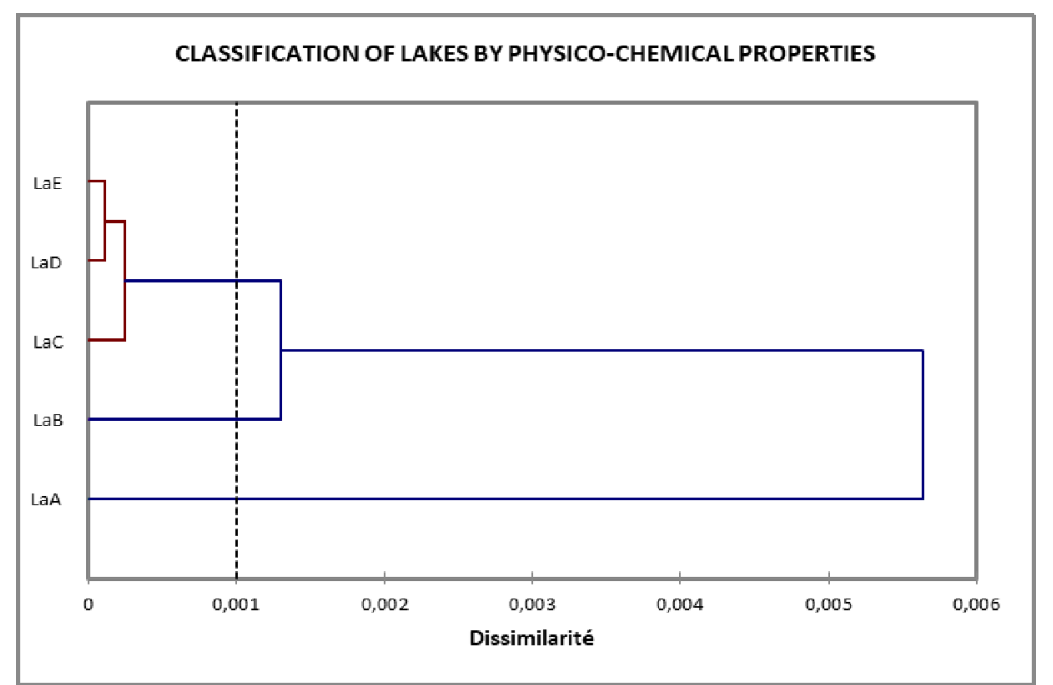

Fig 2: Classification of Yamoussoukro lakes based on their physicochemical characteristics. 


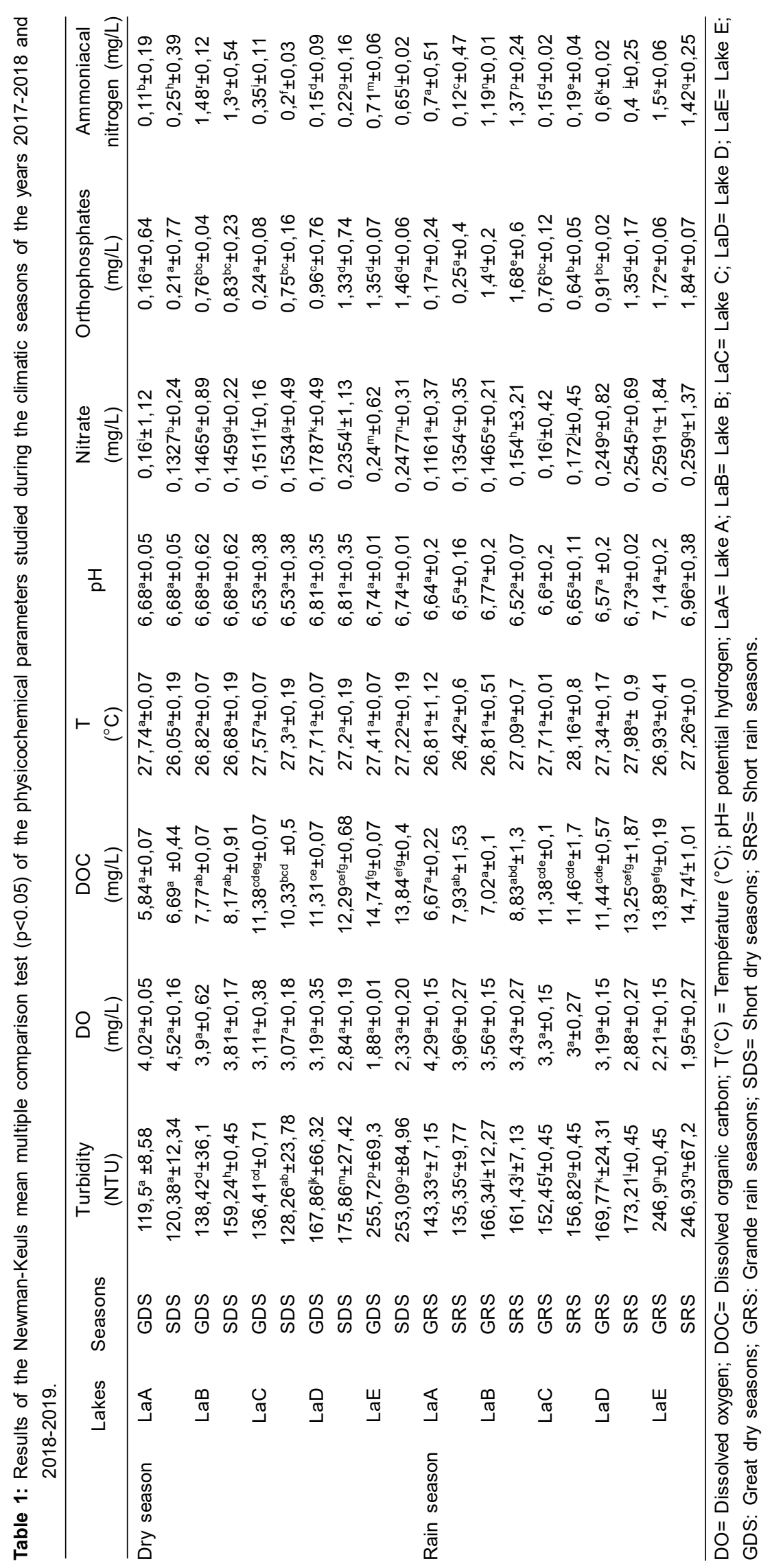



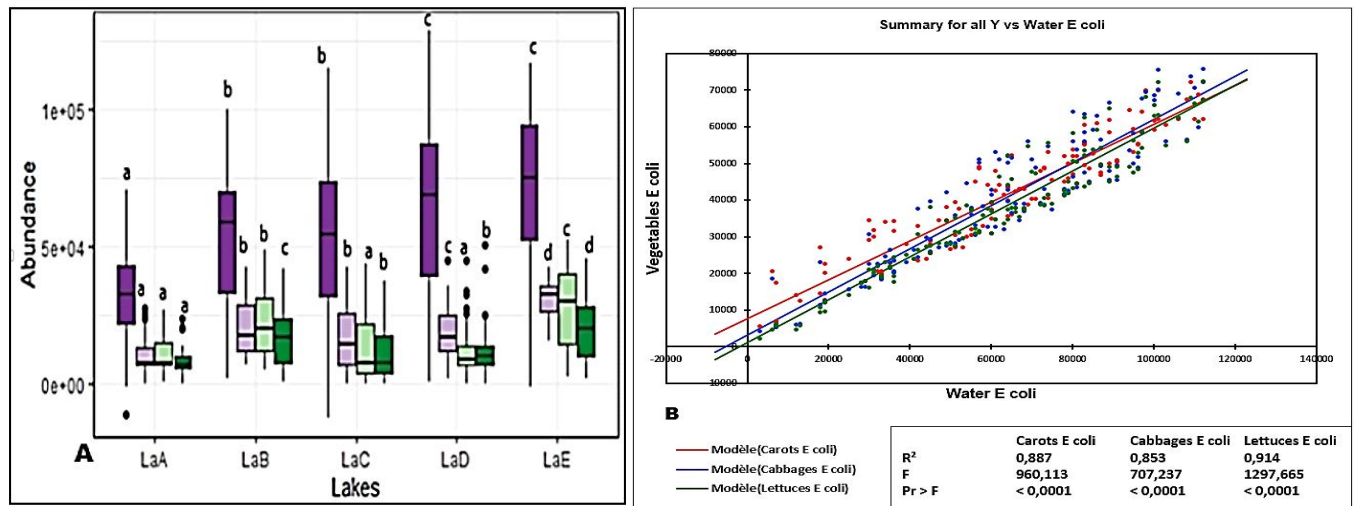

Fig 3: Evolution of the bacterial loads of the vegetables (A) according to the pollution of lakes studied (B)

La: Lake. (Boxes with the same letters are not significantly different according to the Newman-Keuls SDPP test at 5\%).

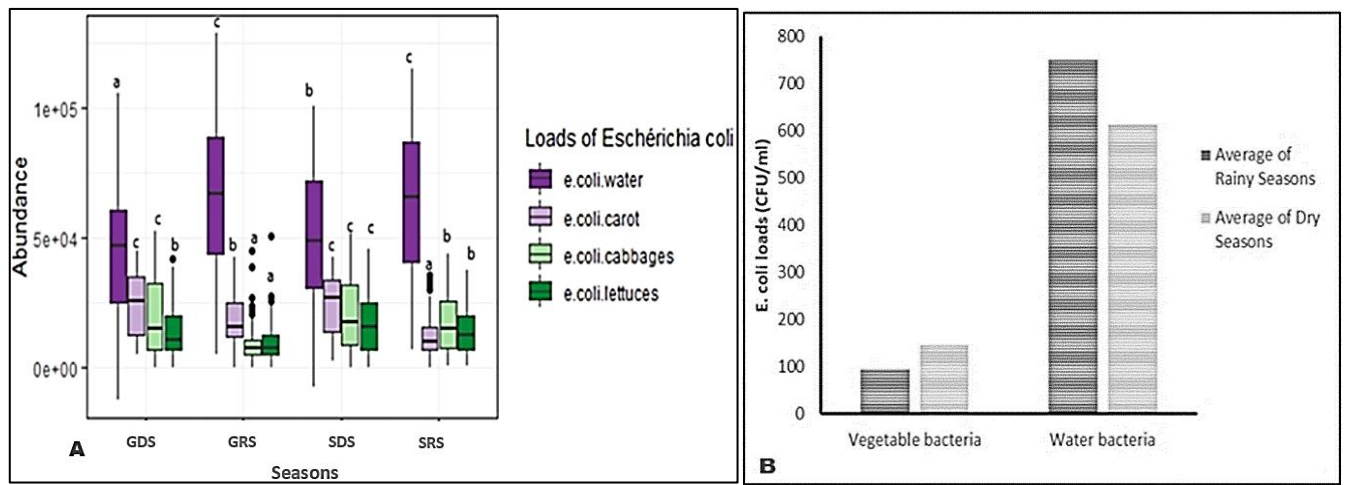

Fig 4: Average loads of Escherichia coli in the different climatic seasons of 2017-2019 (A) and evolution in water and vegetables (B). GDS: Great dry seasons GRS: Great rainy seasons SDS: Small dry seasons SRS: Small rainy seasons.

Table 2: Spearman rank correlation between physico-chemical characteristics of the lake and E. coli abundance on water and vegetables.

\begin{tabular}{lcccccccc}
\hline Variables & $\begin{array}{c}\text { Turbidity } \\
(\mathrm{NTU})\end{array}$ & $\begin{array}{c}\mathrm{DO} \\
(\mathrm{mg} / \mathrm{L})\end{array}$ & $\begin{array}{c}\mathrm{DOC} \\
(\mathrm{mg} / \mathrm{L})\end{array}$ & $\begin{array}{c}\mathrm{T} \\
\left({ }^{\circ} \mathrm{C}\right)\end{array}$ & $\mathrm{pH}$ & $\begin{array}{c}\text { Nitrate } \\
(\mathrm{mg} / \mathrm{L})\end{array}$ & $\begin{array}{c}\text { Orthophosphates } \\
(\mathrm{mg} / \mathrm{L})\end{array}$ & $\begin{array}{c}\text { Ammoniacal } \\
\text { nitrogen }(\mathrm{mg} / \mathrm{L})\end{array}$ \\
\hline Water E. coli & 0,578 & $-0,460$ & 0,612 & 0,028 & 0,041 & 0,473 & 0,469 & 0,472 \\
Carots E. coli & 0,478 & $-0,216$ & 0,473 & 0,016 & 0,039 & 0,525 & 0,533 & 0,567 \\
Cabbages E. coli & 0,395 & $-0,169$ & 0,428 & 0,017 & 0,050 & 0,460 & 0,492 & 0,579 \\
Lettuces E. coli & 0,365 & $-0,137$ & 0,387 & 0,021 & 0,054 & 0,450 & 0,479 & 0,538 \\
\hline
\end{tabular}

depend entirely on rainfall Chase et al. (2019). Consequently, during dry seasons, polluted water used for irrigation contaminates vegetable crops.

\section{Correlation between bacteria loads and lakes water physico-chemical parameters}

Concerning the bacterial parameters and the physicochemical parameters, the most important correlations are those shared between the bacterial abundances of Escherichia coli in waters and parameters such as Turbidity and dissolved organic carbon (DOC). The other parameters do not had a major influence with the evolution of bacterial loads in the waters (Table 2). According to (Ishii and Sadowsky, $2008)$, organic matter (OM) is a variable that promotes bacterial abundance because it provides information on the quantity of nutrients available in the environment. Furthermore, bacterial loads and organic matter (MO) positively correlated with turbidity can be explained according to El-Amier et al., (2015) by the fact that turbidity is generally created by suspended matter such as organic matter debris, living microorganisms and inorganic particles such as silt and clay which are rich elements in organic carbon. Turbidity therefore evolves in the same direction as organic matter $(\mathrm{OM})$ and therefore that microorganisms. (Bilottaa and Brazier, 2008) confirm this result and state that in surface waters turbidity is due to particles rich in organic carbon.

\section{CONCLUSION}

This study shows that the majority of lakes in Yamoussoukro show signs of contamination. All the samples analysed showed more or less significant concentrations of Escherichia coli, which are not in line with the guide values issued by the WHO for surface water. This study clearly 
showed that the bacterial loads in the waters of Lake Yamoussoukro changed with the seasons and the spatial positions of the lakes, independently of the anthropogenic pollution sources of each lake studied, in the lake system. Thus, although the lakes are constantly polluted according to our results; during the rainy seasons, erosion increases pollutants from upstream to downstream of the lakes by runoff. Vegetables, on the other hand, are more at risk during dry seasons. Because of their position, the downstream lakes have maintained the highest pollution levels for both water and cultures. It is therefore important, according to these results, to carry out awareness campaigns on the risks incurred during these periods, with regard to the use of lakes waters or vegetables.

\section{ACKNOWLEDGEMENT}

We would like to thank LANADA-CI for the microbiological analyses on vegetables.

\section{REFERENCES}

Akaninwor, J.O., Anosike, E.O. and Egwim, O. (2007). Effect of indomie industrial effluent discharge on microbial properties of ne Calabar River. Sciences Ressources. 2(1): 1-5.

Amoah, P., Drechsel, P., Abaidoo, R.C. and Henseler, M. (2007). Irrigated urban vegetable production in Ghana: Microbiological contamination in farms and markets and associated consumer risk groups. Journal of Water and Health. 05-3.

Anoman, T.M., Voko, D.B.R. and Zeze, A. (2019). Spatial and temporal dynamics of coliform contamination within Yamoussoukro lakes water in Côte d' Ivoire: Impact on the safety of surrounding vegetable cropping. Microbiology and Nature. 1: 29-43.

Bilottaa, G.S. and Brazier, R.E. (2008). Understanding the influence of suspended solids on water quality and aquatic biota. Water Research. 42: 2849-2861.

Birnboim, H.C., Doly, J. (1979). A rapid alkaline extraction procedure for screening recombinant plasmid DNA. Nucleic Acids Research. 7(6): 1513-1523. http://doi.org/10.1093/nar/ 7.6.1513.

Chase, J.A., Partyka, M.L., Bond, R.F. and Atwill, E.R. (2019). Environmental inactivation and irrigation-mediated regrowth of Escherichia coli O157:H7 on romaine lettuce when inoculated in a fecal slurry matrix. Peer. J. 7: 65-91.

Edosomwan, N.L. and Onwumah B.I. (2008). Impact of municipal solid waste on some soil properties in central southern Nigeria. Indian Journal of Agricultural Research. 42: 244-251

El-Amier, Y., Zahran, M. and Al-Mamory, S. (2015). Assessment the Physico-Chemical Characteristics of Water and Sediment in Rosetta Branch, Egypt. Journal of Water Resource and Protection. 7: 1075-1086.

Emon, M., Surajit, H. and Dhriti, B. (2020). Effect of environment and elevation on seasonal prevalence of culicoides in West Bengal. Indian Journal of Animal Research. 54(9): $1125-1135$.

FAO (Food and Agriculture Organisation of the United Nations) (2008). A Strategic Framework for Reducing Risks of Infectious Diseases at the Animal-Human-Ecosystems Interface. Available at: https://www.fao.org/3/aj137e/ aj137e00.htm.
Fricker C.R., Bullock S., Murrin K., Niemela, S.I. (2008). Use of the ISO 9308-1 procedure for the detection of Eschérichia coli in water utilizing two incubation temperatures and two confirmation procedures and comparison with defined substrate technology. Journal of Water and Health. 6: 389-397.

Holvoet, K., Sampers, I., Seynnaeve, M., Jacxsens, L. and Uyttendaele, M. (2015). Agricultural and Management Practices and Bacterial Contamination in Greenhouse versus Open Field Lettuce Production. International Journal of Environmental Research and Public Health. 12: 32-63.

Ishii, S. and Sadowsky, M.J. (2008). Eschérichia coli in the environments: Implication for water quality and human health. Microbes and Environments. 23(2): 101-108. doi: 10.1264/jsme2.23.101.

Kanwar, J.S. and Sandha, M.S. (2000). Waste water pollution injury to vegetable crops-A review. Agricultural Reviews. 21(2): 133-136.

MDDEFP (Ministère du Developpement durable de l'Environnement de la Faune et des Parcs) (2013). Guide pour l'évaluation de la qualité bactériologique de l'eau en lac. Québec. Direction Du Suivi de l'état de l'environnement, 30 p. + 1 annexe. Available at: http://www.mddelcc.gouv.qc.ca/eau/ rsvl/Guide-eval-bacteriologique-eau-lac.pdf.

N'Guessan, K., Konan, K., Bony, K. and Edia, O. (2011). Prospects for rehabilitation of man-made lake system of Yamoussoukro (Ivory Coast). Procedia Environmental. 9: 140-147.

Rodier, J. (2009). Analyse de l'eau, 9ème édition. Rodier, Jean Dunod Paris. 1959, ISBN 97821000724602100072463.

Schmidt, P.J., Emelko, M.B., Reilly, P.M. (2010). Quantification of analytical recovery in particle and microorganism enumeration methods. Environmental Science and Technology. 44(5): 1705-1712.

Shivakrishna, A., Ramteke, K., Dhanya, M., Charitha, R., Aktar,S., Singh, R. and Abidi, Z.J. (2020). Spatio-temporal distribution of water quality parameters in ramsar site-Kolleru Lake. Indian Journal of Animal Research. 54(6): 753-760.

Sylla, I., Koffi, M., N'dri, K., Bony, K. and Konan K. (2019). Évaluation de la diversité et de la charge parasitaire des lacs de la ville de Yamoussoukro en Côte d'Ivoire. Journal of Applied Biosciences. 134: 13630-13642.

Tano, B.F., Abo, K., Dembele, A. and Fondio, L. (2011). Systèmes de production et pratiques à risque en agriculture urbaine/ : cas du maraîchage dans la ville de Yamoussoukro en Côte d'Ivoire. International Journal of Biological and Chemical Sciences. 5: 2317-2329.

Tsai, L.Y., Palmer, C.L., Sangeermano, L.R. (1993). Detection of Eschérichia coli in sludge by polymerase chain reaction. Applied and Environmental Microbiology. 59: 353-357.

USDA (United States Department of Agriculture) (2014). Good Agricultural Practices (GAP) and Good Handling Practices (GHP). Available at: https://www.ams.usda.gov/ sites/default.pdf.

WHO (World Health Organization) (2012). Micro-organismes. Available at: https://www.who.int/water_sanitation_health/ publications/gdwq4-with-add-fr-chap11.pdf. 